\title{
The scleractinian Agaricia undata as a new host for the coral-gall crab Opecarcinus hypostegus at Bonaire, southern Caribbean
}

\author{
Jaaziel E. García-Hernández ${ }^{1}$ (D) $\cdot$ Werner de Gier $^{2,3}$ (D) $\cdot$ Godfried W. N. M. van Moorsel ${ }^{4,5}$ (D) $\cdot$ Bert W. Hoeksema ${ }^{2,3,6}$ (D)
}

Received: 20 May 2020 / Accepted: 8 August 2020 / Published online: 20 August 2020

(C) The Author(s) 2020

\begin{abstract}
The Caribbean scleractinian reef coral Agaricia undata (Agariciidae) is recorded for the first time as a host of the coral-gall crab Opecarcinus hypostegus (Cryptochiridae). The identity of the crab was confirmed with the help of DNA barcoding. The association has been documented with photographs taken in situ at $25 \mathrm{~m}$ depth and in the laboratory. The predominantly mesophotic depth range of the host species suggests this association to be present also at greater depths. With this record, all seven Agaricia species are now listed as gall-crab hosts, together with the agariciid Helioseris cucullata. Within the phylogeny of Agariciidae, Helioseris is not closely related to Agaricia. Therefore, the association between Caribbean agariciids and their gallcrab symbionts may either have originated early in their shared evolutionary history or later as a result of host range expansion. New information on coral-associated fauna, such as what is presented here, leads to a better insight on the diversity, evolution, and ecology of coral reef biota, particularly in the Caribbean, where cryptochirids have rarely been studied.
\end{abstract}

Keywords Associated fauna $\cdot$ Brachyura $\cdot$ Coral reefs $\cdot$ Cryptochiridae $\cdot$ Marine biodiversity $\cdot$ Symbiosis

\section{Introduction}

Reef coral species of various scleractinian families are known to host coral-gall crabs of the brachyuran family Cryptochiridae. These crabs dwell inside pits or galls inside the coral skeleton (Castro 1976, 2015; Klompmaker et al. 2016; Chan et al. 2020). In addition to Cryptochiridae, species of some other brachyuran families live inside scleractinian corals and modify their skeletons, such as the domeciid crab Domecia acanthophora (Desbonne and Schramm, 1867)

Bert W. Hoeksema

bert.hoeksema@naturalis.nl

1 Marine Genomic Biodiversity Laboratory, University of Puerto Rico-Mayagüez, La Parguera, PR 00667, USA

2 Taxonomy and Systematics Group, Naturalis Biodiversity Center, P.O. Box 9517, 2300, RA Leiden, The Netherlands

3 Groningen Institute for Evolutionary Life Sciences, University of Groningen, P.O. Box 11103, 9700, CC Groningen, The Netherlands

4 Ecosub, Berkenlaantje 2, 3956, DM Leersum, The Netherlands

5 ANEMOON Foundation, P.O. Box 29, 2120, AA

Bennekom, The Netherlands

6 Institute of Biology Leiden, Leiden University, P.O. Box 9505, 2300, RA Leiden, The Netherlands living in association with species of the genus Acropora (Acroporidae) in the western Atlantic (Hoeksema and García-Hernández 2020). Although there is disagreement on whether to consider coral-gall crabs parasites or commensals, they are known to feed on their hosts and hinder their growth, and therefore the argument for parasitism is strongest (SimonBlecher and Achituv 1997; Simon-Blecher et al. 1999; Klompmaker and Boxshall 2015).

Since much of the biodiversity of coral reefs consists of coral-associated fauna, from an evolutionary point of view, it is important to examine host-specificity in coral-dwelling crabs and whether they display specific host-dependent genetic divergence (van Tienderen and van der Meij 2017). With over 1600 scleractinian species on record (Hoeksema and Cairns 2020a), however, it is far from clear which coral taxa actually host gall crabs. This information would help to clarify which coral species are inhabited by cryptochirds and which ones are not, and whether such presence-absence patterns have the same evolutionary origin. The latter may, however, be less obvious when host switching is taken into consideration (Hoeksema et al. 2018). Furthermore, since some closely related coral species have different bathymetric ranges (Hoeksema 2012; Bongaerts et al. 2013; Muir et al. 2015; Roberts et al. 2019), the presence-absence of crab inhabitation may also depend on particular depth limits of their hosts, like for Christmas tree worms (Polychaeta, Serpulidae, 
Spirobranchus) ranging from 2 to $39 \mathrm{~m}$ depth (Hoeksema and ten Hove 2017; Hoeksema et al. 2020).

It is unclear whether zooxanthellate coral species common in the surf zone or at mesophotic depths $(>30 \mathrm{~m})$ possess crab galls. Only a few examples from deep water are known and these are limited to the family Agariciidae, such as the cryptochirid Luciades agana Kropp and Manning, 1996 in the coral Leptoseris papyracea (Dana, 1846) at 128-137 m depth off Guam (Kropp and Manning 1996) and at $34 \mathrm{~m}$ depth in Tonga (Komatsu and Takeda 2013). Another example is Opecarcinus hypostegus (Shaw and Hopkins 1977) in Agaricia lamarcki Milne Edwards and Haime, 1851 at $60 \mathrm{~m}$ depth off Curaçao (van der Meij et al. 2015). Cryptochirids are also known to live in azooxanthellate deep-sea corals, such as Cecidocarcinus brychius Kropp and Manning, 1987 at 512-686 m depth in a dendrophyliid off Namibia, SE Atlantic (Zibrowius and Gili 1990), and Cecidocarcinus zibrowii Manning, 1991 off New Caledonia at 425-440 $\mathrm{m}$ depth in the West Pacific (Manning 1991). In order to increase our understanding of the evolutionary history of these associations, it is relevant to expand our knowledge regarding cryptochirids in relation to the bathymetrical ranges and phylogenetic relationships of their host taxa. This is crucial since our knowledge of these associations could be biased by depth limitations set by SCUBA diving limits. This could particularly be true in the Caribbean, where few records are known in comparison with the Indo-West Pacific region (van der Meij and Nieman 2016; Chan et al. 2020).

The Agariciidae is one of only a few coral families with cryptochirid records from the Caribbean, Indo-West Pacific, and Eastern Pacific. These records are represented by cryptochirid species of Opecarcinus Kropp and Manning, 1987 (Kropp 1989; van der Meij 2014a, 2014b; Chan et al. 2020) and two monospecific cryptochirid genera in the IndoWest Pacific. The latter are Luciades Kropp and Manning, 1996, represented by L. agana in association with Leptoseris papyracea (mentioned above) and Pseudohapalocarcinus Fize and Serène, 1956, represented by $P$. ransoni Fize and Serène, 1956, in association with Pavona frondifera (Lamarck, 1816) (Fize and Serène 1956; Takeda and Tamura 1980) and Pavona cactus (Forskål, 1775) (van der Meij and Nieman 2016). Although information on Opecarcinus distributions seems to be scarce, apart from host and depth records, only the Indo-West Pacific O. cathyae van der Meij, 2014, has received special attention. This species is reported to show a wide geographical distribution and extremely high abundances (Hoeksema and van der Meij 2013; van der Meij et al. 2018). Because cryptochirids are small and usually hide inside their dwellings, they are easily overlooked and their prevalence on coral reefs may be commonly underestimated (Simon-Blecher and Achituv 1997; Nogueira et al. 2014).

The first record of gall crabs associated with Caribbean agariciids dates to 1977, with the description of Opecarcinus hypostegus in Florida (Shaw and Hopkins 1977) from Agaricia fragilis (Table 1). Additional host-coral species were discovered, especially within the last five years, including Helioseris cucullata in 2017 and Agaricia tenuifolia in 2018, both in the Caribbean Netherlands (Table 1). Agaricia consists of seven species (Hoeksema and Cairns 2020b), with only one species, A. undata, not previously recorded as a host. This coral is best known for its predominantly mesophotic bathymetrical range, from 17 to $87 \mathrm{~m}$ in the Colombian Caribbean (Gonzalez-Zapata et al. 2018), from 60 to $90 \mathrm{~m}$ at Curaçao (Bongaerts et al. 2015), and from 70 to $90 \mathrm{~m}$ at Puerto Rico (Appeldoorn et al. 2016, 2019). Here we report the first record of $A$. undata as host for the gall crab Opecarcinus hypostegus and discuss its possible evolutionary and ecological relevance.

\section{Material and methods}

During a marine biodiversity survey at Bonaire (22 October 9 November 2019), Caribbean Netherlands (previously known as Netherlands Antilles, see Hoeksema et al. 2017a), we studied the occurrence of corals and associated fauna at 35 stations using the roving diver technique (Hoeksema and Koh 2009). Scuba diving was performed to a maximum depth of $30 \mathrm{~m}$. Special attention was given to coral species and their interspecific interactions with other benthic fauna, particularly rarely recorded species. Stony corals were identified using Wells (1973) and Reyes et al. (2010).

Three specimens of cryptochirids were collected for identification, one female and two males. Published illustrations of type material only consist of line drawings (Shaw and Hopkins 1977; Kropp and Manning 1987) and a previously published photograph shows a crab without host and locality data (Santana et al. 2016). Photographs of a male and a female collected from the Brazilian endemic scleractinian Siderastrea stellata Verrill, 1868 (Johnsson et al. 2006: Fig. 3), probably concern Kroppcarcinus siderastreicola Badaró et al., 2012, a common species in Brazil (Badaró et al. 2012; Nogueira et al. 2014), which also occurs in the Caribbean (van der Meij et al. 2014b). Therefore, in order to obtain a reliable identification for the crab associated with Agaricia undata in Bonaire, DNA barcoding was applied.

Genomic DNA of gall crabs was extracted with the DNeasy Blood and Tissue Isolation Kit (QIAGEN) using the manufacturer's instructions. Two walking legs per specimen were lysed overnight in lysis buffer ATL and Proteinase $\mathrm{K}$ at $56{ }^{\circ} \mathrm{C}$. First and second elution steps were done with $200 \mu \mathrm{l}$ and $50 \mu \mathrm{l}$ AE buffer respectively. A polymerase chain reaction (PCR) was carried out by using a cocktail of two primer mixes (M13F-LepFolF mix: 5'- TGT AAA ACG ACG GCC AGT RKT CAA CMA ATC ATA AAG ATA TTG $\mathrm{G}-$ 3' $^{\prime}$ and M13R-LepFolR mix: 5' - CAG GAA ACA GCT ATG ACT AAA CTT CWG GRT GWC CAA AAA ATC $-3^{\prime}$ ) with an amplification product between the primers 
Table 1 Records of Caribbean Agariciidae as host corals for gall crabs

\begin{tabular}{ll}
\hline Species & Localities [references] \\
\hline Agaricia agaricites (Linnaeus, 1758) & Puerto Rico [2], Jamaica [3], Curaçao [4,6] \\
Agaricia fragilis Dana, 1846 & Florida [1,2], Curaçao [4,6] \\
Agaricia grahamae Wells, 1973 & Jamaica [3], Curaçao [4,6] \\
Agaricia humilis Verrill, 1902 & Curaçao [4,6] \\
Agaricia lamarcki Milne Edwards and Haime, 1851 & Jamaica [3], Curaçao [4,5,6] \\
Agaricia tenuifolia Dana, 1846 & Bonaire [8] \\
Agaricia undata (Ellis and Solander, 1786) & Bonaire [present study] \\
Helioseris cucullata (Ellis and Solander, 1786) & St. Eustatius [7] \\
Leptoseris cailleti (Duchassaing and Michelotti, 1864) & no record \\
\hline
\end{tabular}

References: [1] Shaw and Hopkins (1977); [2] Kropp and Manning (1987); [3] Scott (1987); [4] van der Meij (2014b); [5] van der Meij et al. (2015a); [6] van Tienderen and van der Meij (2016, 2017); [7] Hoeksema et al. (2017a); [8] van Moorsel and van der Meij et al. (2018) of 658 base pairs (bp). The M13F-LepFolF primer mix was a combination of M13F-LepF1 and M13F-LCO1490, and the M13R-LepFolR primer mix was a combination of M13RLepR1 and M13R-HCO2198 (Folmer et al. 1994; Herbert et al. 2004). A PCR amplification of the mitochondrial COI was performed in a volume of $25 \mu$ containing $2 \mu \mathrm{l}$ DNA template, $2.5 \mu$ of 10x PCR Coralload PCR buffer (Qiagen), $0.5 \mu \mathrm{l}$ of $10 \mu \mathrm{M}$ of all four primers, $0.5 \mu \mathrm{l}$ of $2.5 \mathrm{mM} \mathrm{dNTP}$, and $0.25 \mu \mathrm{l}$ of $5 \mathrm{U} / \mu \mathrm{l}$ Taq DNA polymerase (Qiagen). Standard PCR conditions were used: initial denaturation at $96{ }^{\circ} \mathrm{C}$ for $3 \mathrm{~min}, 40$ cycles of: denaturation at $96{ }^{\circ} \mathrm{C}$ for $15 \mathrm{~s}$, annealing at $50{ }^{\circ} \mathrm{C}$ for $1 \mathrm{~min}$, elongation at $72{ }^{\circ} \mathrm{C}$ for $1 \mathrm{~min}$, and a final elongation step at $72{ }^{\circ} \mathrm{C}$ for $5 \mathrm{~min}$ ). PCR products were visualized by agarose gel electrophoresis ( $1 \%$ agarose gel). Suitable amplicons were sequenced by BaseClear Leiden using the M13-tailed primers (forward and reverse sequencing).

Raw sequences were edited by using MEGA X (v. 10.0.5; Kumar et al. 2018) and trimmed to $623 \mathrm{bp}$ for analysis. For the purpose of molecular identification, a Maximum Likelihood (ML) tree with 500 bootstrap replicates was constructed to show the phylogenetic affinities to three other crab species from the same genus, along with two outgroup species (Table 2). Newly obtained sequences of COI were deposited in NCBI under the accession numbers MT488422MT488424 (Table 2).
Table 2 Information on sequences used in the phylogenetic analysis of coralgall crabs in relation to their host corals

\begin{tabular}{llll}
\hline Species & Genbank nr. & Host coral & Locality (reference) \\
\hline Opecarcinus hypostegus (female) & MT488423 & Agaricia undata & Bonaire, Caribbean [1] \\
O. hypostegus (male) & MT488424 & A. undata & Bonaire, Caribbean [1] \\
O. hypostegus (male) & MT488422 & A. undata & Bonaire, Caribbean [1] \\
O. hypostegus & KY026324 & Agaricia agaricites & Curaçao, Caribbean [2] \\
O. hypostegus & KY026344 & A. agaricites & Curaçao, Caribbean [2] \\
O. hypostegus & KY026355 & A. agaricites & Curaçao, Caribbean [2] \\
O. hypostegus & KY026400 & Agaricia fragilis & Curaçao, Caribbean [2] \\
O. hypostegus & KY026230 & Agaricia grahamae & Curaçao, Caribbean [2] \\
O. hypostegus & KY026249 & Agaricia humilis & Curaçao, Caribbean [2] \\
O. hypostegus & KY026296 & Agaricia lamarcki & Curaçao, Caribbean [2] \\
O. hypostegus & KY026380 & A. lamarcki & Curaçao, Caribbean [2] \\
Opecarcinus cathyae & KY013342 & Pavona sp. & Malaysia, Pacific Ocean [3] \\
O. cathyae & KY013334 & Pavona sp. & Saudi Arabia, Red Sea [3] \\
Opecarcinus lobifrons & KJ923666 & Gardineroseris planulata & Malaysia, Pacific Ocean [4] \\
O. lobifrons & KJ923670 & G. planulata & Indonesia, Pacific Ocean [4] \\
Opecarcinus pholeter & KU041833 & Pavona explanulata & Indonesia, Pacific Ocean [5] \\
Pseudohapalocarcinus ransoni & KJ923668 & Pavona cactus & Malaysia, Pacific Ocean [5] \\
Kroppcarcinus siderastreicola & KU041837 & Siderastrea siderea & Curaçao, Caribbean [5] \\
\hline
\end{tabular}

References: [1] this study; [2] van Tienderen and van der Meij (2017); [3] van der Meij et al. (2018); [4] van der Meij and Reijnen (2014); [5] van der Meij and Nieman (2016) 

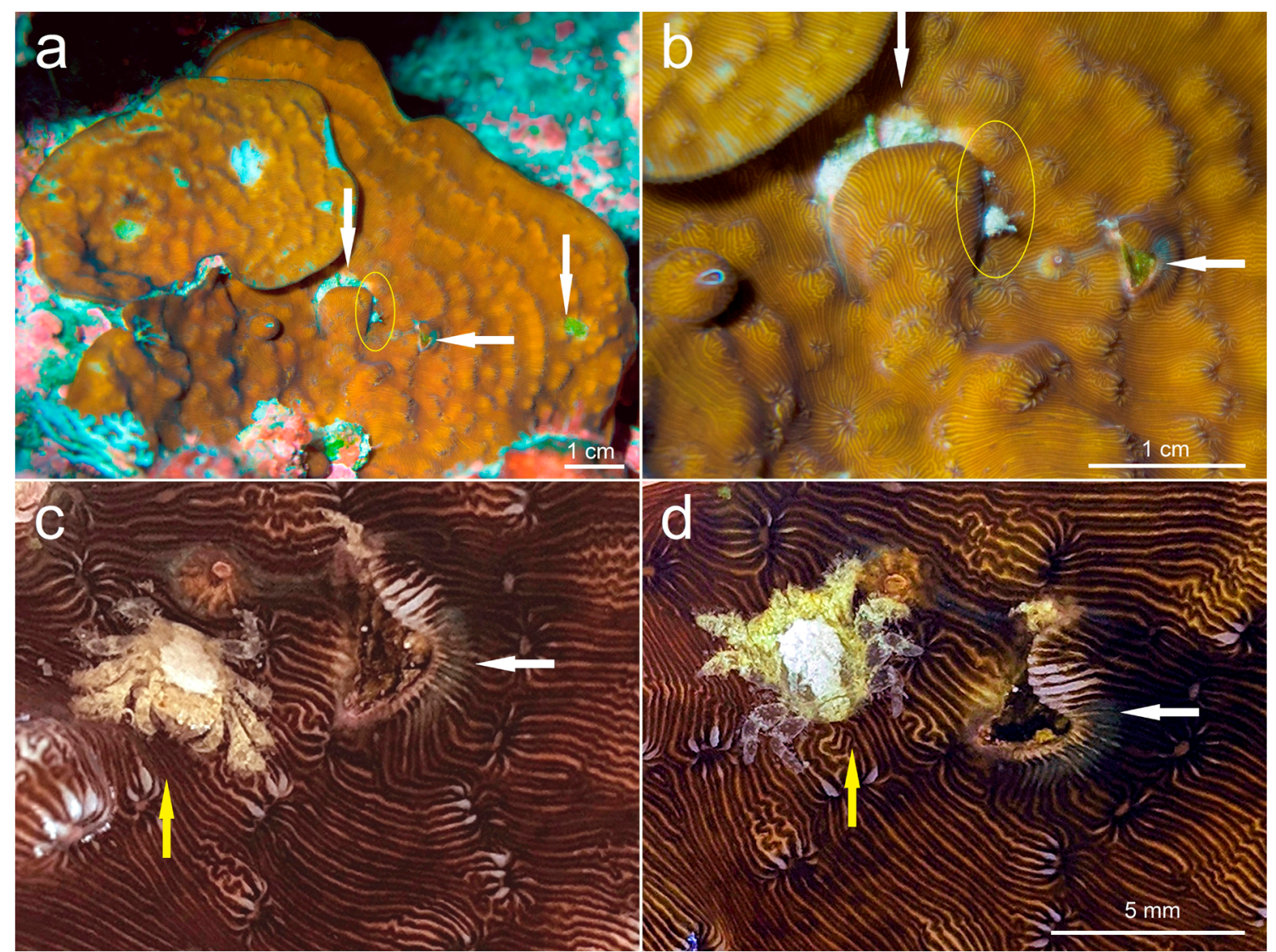

Fig. 1 Agaricia undata at $25 \mathrm{~m}$ depth, Willemstoren Lighthouse, Bonaire, with gall crabs (yellow ellipses and arrows) and their pits (white arrows). a. Overall view of the host coral; b. Close-up showing calice pattern and position of gall crab pits, and one pair of crabs leaving

One female and one male specimen were photographed (Figs. 1c, 2) to be used as reference for future studies. The three specimens were deposited in the Crustacea collection of Naturalis Biodiversity Center, Leiden as reference material (catalogue numbers RMNH.CRUS.D.57958, 57959, 57960, respectively).

\section{Results}

A shore dive on the wave-exposed reef in front of Willemstoren Lighthouse $\left(12^{\circ} 01^{\prime} 39^{\prime \prime} \mathrm{N} 68^{\circ} 14^{\prime} 12^{\prime \prime} \mathrm{W}\right)$ on the southern coast of Bonaire (29 October 2019) resulted in the discovery of one specimen of Agaricia undata at ca. $25 \mathrm{~m}$ depth (Fig. 1a, b). This particular colony was occupied by three coral crabs (Fig. 1c, d), one female and two males (Fig. 2). The dwellings were typical for Opecarcinus hypostegus as encountered in various Agaricia spp. hosts (Kropp 1989; van der Meij et al. 2015; van Tienderen and van der Meij 2017; van Moorsel and van der Meij 2018). We provisionally assumed that it concerned Opecarcinus hypostegus, based on the crab's dwelling as in previous the pit (yellow ellipse; RMNH.CRUS.D.57958, 57959); c,d. One male crab inside a pit (white arrow; RMNH.CRUS.D.57960) and the female walking around after capture and release (yellow arrow; RMNH.CRUS.D.57958)

studies (van der Meij et al. 2015; Hoeksema et al. 2017c; van Moorsel and van der Meij 2018). Agaricia undata was observed and documented at two other sites around Bonaire, but in these cases no associates were found.

DNA barcoding confirmed the identification of the specimens as $O$. hypostegus (Fig. 3). In the phylogenetic tree, the three crab specimens were distributed over various branches, mixing with crabs collected from other Agaricia spp. Therefore, our molecular data confirm the first record of a cryptochirid symbiont of $A$. undata, implying that all Agaricia species are known to host gall crabs, together with Helioseris cucullata (Table 1). Leptoseris cailleti remains as the only Caribbean agariciid without a record of a cryptochirid symbiont (Table 1) or any other associated invertebrate (see Scott 1985, 1987).

The identification of the coral as Agaricia undata was confirmed after the descriptions in Wells (1973) and Reyes et al. (2010). To the untrained eye, A. undata can be easily confused with A. grahamae. Both species occur predominantly in the mesophotic zone (Sherman et al. 2010; Bongaerts et al. 2015; Appeldoorn et al. 2016; Hoeksema et al. 2017b; Sánchez et al. 2019). The calices of $A$. undata are mostly arranged in rows 
Fig. 2 Female and male gall crab specimens of Opecarcinus hypostegus (RMNH.CRUS.D.57958, 57959, respectively) collected from the host coral Agaricia undata at Bonaire

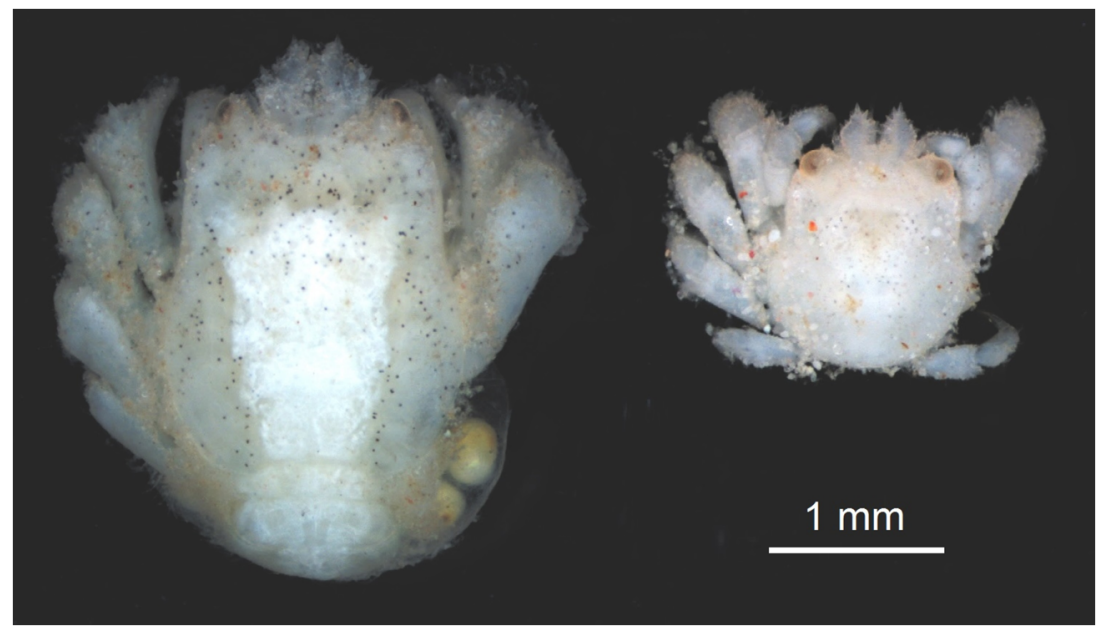

underneath ridges with rounded tops, directing in outward direction, but starting more or less separated (Fig. 1b), whereas those of A. grahamae are positioned on the bottom of long v-shaped valleys (Wells 1973; Reyes et al. 2010). These distinguishing characters are not clear in relatively young specimens.

\section{Discussion}

Based on previous records and the present observations, it appears that all Agaricia spp. in the Caribbean, along with the agariciid Helioseris cucullata (Table 1), share the same cryptochirid species, O. hypostegus. In Brazil, O. hypostegus has been reported from Agaricia fragilis and A. agaricites (Johnsson et al. 2006; Badaró et al. 2012; Santana et al. 2016). Older records of $O$. hypostegus from non-agariciid hosts (e.g. Scott 1985; Nogueira 2003) are doubtful and probably concern misidentified crabs of recently discovered species (Badaró et al. 2012; Canário et al. 2015; Hoeksema et al. 2017c).

Few cryptochirids in these associations have had their identities verified with the help of barcoding. It should be noted that the other species of Opecarcinus, including $O$. lobifrons in the widespread coral Gardineroseris planulata as the sister species of $O$. hypostegus (Table 2), are from the Indo-West Pacific, and some of these are also from the Eastern Pacific (Kropp 1989; Wei et al. 2005; van der Meij and Nieman 2016). Within the phylogeny of the Agariciidae, however, Agaricia and Helioseris are not closely related (Huang 2012; Kitahara et al. 2012). Furthermore, the identity of the crab species in A. tenuifolia and H. cucullata still needs to be verified, since their preliminary identifications are based on the morphology of their dwellings. The Caribbean agariciid genera are thus not monophyletic and a shared cryptochirid symbiont should be either the result of a very early evolutionary

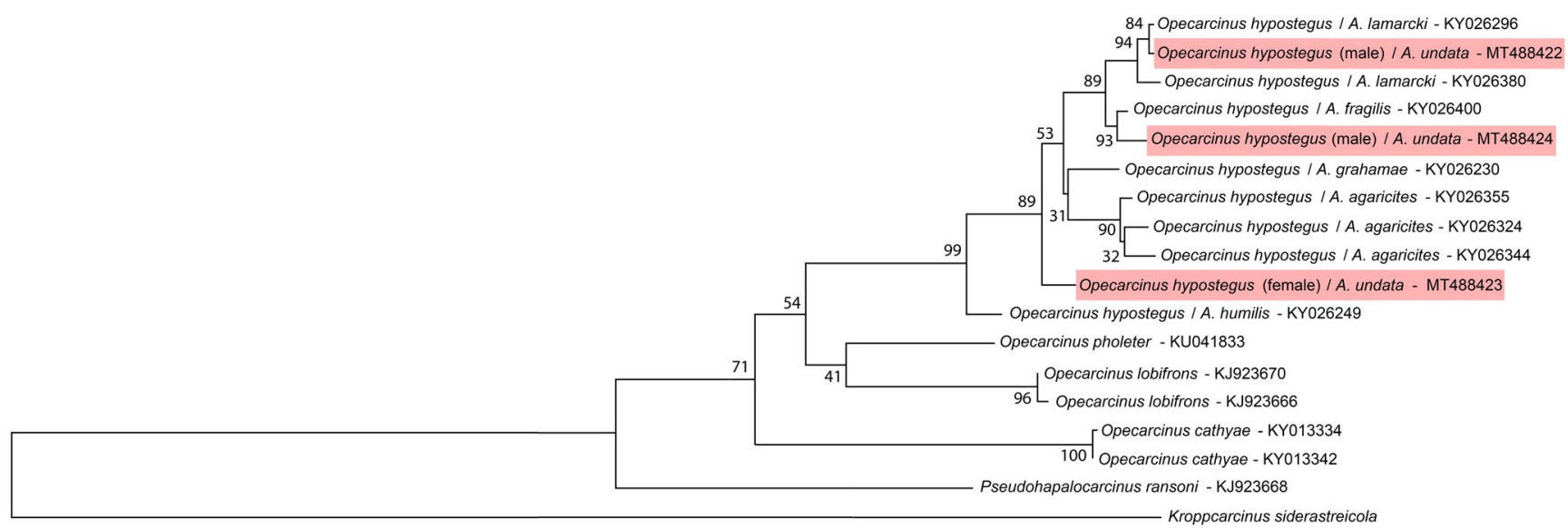

0.10

Fig. 3 Phylogenetic analysis based on the COI mitochondrial gene of a subset of Opecarcinus species and two related outgroup species (Table 2). Host coral species of the Caribbean reef coral genus Agaricia are specified. Maximum Likelihood (ML) tree with Bootstrap values. Specimens from this study are highlighted in red 
origin of the cryptochirid coral association or of a more recent host range expansion.

That all Agaricia spp. share a common cryptochirid symbiont is perhaps not surprising. There are also examples of scleractinian genera in other families, e.g. Fungiidae (see Gittenberger et al. 2011; Benzoni et al. 2012; Hoeksema 2014), in which cryptochirid symbionts have been found in only a limited number of species (Centactis, Cycloseris) or in none at all (Cantharellus, Heliofungia) (van der Meij et al. $2015 \mathrm{~b}$ ). The present finding and other recently discovered crab-coral associations (van der Meij 2015, 2017; Hoeksema et al. 2017c; van Moorsel and van der Meij 2018) suggest that missing host records are partly due to insufficient sampling.

Because A. undata is most abundant at depths $>25 \mathrm{~m}$ (Fenner 1999), the present discovery contributes to our understanding of similarities in reef faunas among the mesophotic and shallower parts of the reef slopes ( $<30 \mathrm{~m}$ depth). Opecarcinus hypostegus was previously reported from $60 \mathrm{~m}$ depth in association with $A$. lamarcki (van der Meij et al. 2015a). If mesophotic zones are potential refugia for coral reef fauna (Rooney et al. 2010; Slattery et al. 2011; Semmler et al. 2017; Baldwin et al. 2018), future surveys of mesophotic reefs should not only focus on the occurrence of deep-living corals but also on the occurrence of other coral-associated organisms (Hoeksema et al. 2017c; Veglia et al. 2018; Korzhavina et al. 2019).

Leptoseris cailleti is the only Caribbean agariciid in need of investigation of its associated fauna (Table 1). This deepwater species has only been recorded from depths $>33 \mathrm{~m}$ (Dinesen 1980; Fenner 2001; Garcia-Sais et al. 2007, 2011) and is the only Leptoseris species in the Caribbean (Muir and Pichon 2019), whereas all of its presently known congeners are from the Indo-West Pacific (Waheed et al. 2015) and some from the Eastern Pacific (Glynn et al. 2017). A possible candidate gall-crab associate could belong to an undescribed species of Luciades, the only cryptochirid genus known to be represented in Indo-West Pacific Leptoseris corals (Kropp and Manning 1996; Wetzer et al. 2009). Leptoseris papyracea (Dana, 1846), host of Luciades agana at Guam and Tonga (Komatsu and Takeda 2013), also occurs in the Eastern Pacific, but here it is not yet known to host cryptochirids. Crabs of the genus Opecarcinus would require a host expansion in order to become associated with Caribbean Leptoseris. The latter genus is phylogenetically more closely related to the Indo-Pacific agariciid genus Pavona than to the West Atlantic / Caribbean genus Agaricia (Huang 2012). Because the family Agariciidae is widespread in tropical areas and is represented in a wide depth range (Muir et al. 2018; Muir and Pichon 2019), it is well suited for studies on the evolution and biogeography of coral-associated faunas.

Acknowledgements Fieldwork at Bonaire was supported by the WWF Netherlands Biodiversity Fund, the Treub Maatschappij - Society for the
Advancement of Research in the Tropics, and the Nature of the Netherlands programme of Naturalis Biodiversity Center. The first author thanks Naturalis Biodiversity Center and the previously mentioned funding agencies for supporting this research. The second author would like to thank the L.B. Holthuis Fonds and the Jan Joost ter Pelkwijk Fonds for financial support. We thank staff of STINAPA Bonaire and Dutch Caribbean Nature Alliance (DCNA) for assistance in the application of the research permit. Dive Friends (Bonaire) and Budget Car Rental provided logistic support. The authors like to thank the other expedition members of the Bonaire Marine Biodiversity Expedition (2019) for their companionship and help. F. Andres Rivera-Quiroz assisted with the photography (Fig. 2). We are grateful to two anonymous reviewers and the editor for their helpful comments.

Open Access This article is licensed under a Creative Commons Attribution 4.0 International License, which permits use, sharing, adaptation, distribution and reproduction in any medium or format, as long as you give appropriate credit to the original author(s) and the source, provide a link to the Creative Commons licence, and indicate if changes were made. The images or other third party material in this article are included in the article's Creative Commons licence, unless indicated otherwise in a credit line to the material. If material is not included in the article's Creative Commons licence and your intended use is not permitted by statutory regulation or exceeds the permitted use, you will need to obtain permission directly from the copyright holder. To view a copy of this licence, visit http://creativecommons.org/licenses/by/4.0/.

\section{References}

Appeldoorn R, Ballantine D, Bejarano I, Carlo M, Nemeth M, Otero E, Pagan F, Ruiz H, Schizas N, Sherman C, Weil E (2016) Mesophotic coral ecosystems under anthropogenic stress: a case study at Ponce, Puerto Rico. Coral Reefs 35:63-75. https://doi.org/10.1007/s00338015-1360-5

Appeldoorn R, Alfaro M, Ballantine DL, Bejarano I, Ruiz HJ, Schizas NV, Schmidt WE, Sherman CE, Weil E (2019) Puerto Rico. In: Loya Y, Puglise KA, Bridge TCL (eds) Mesophotic coral ecosystems, Coral reefs of the world, vol 12. Springer Nature, Cham, pp 111-129. https://doi.org/10.1007/978-3-319-92735-0 7

Badaró MFS, Neves EG, Castro P, Johnsson R (2012) Description of a new genus of Cryptochiridae (Decapoda, Brachyura) associated with Siderastrea (Anthozoa, Scleractinia), with notes on feeding habits. Sci Mar 76:517-526. https://doi.org/10.3989/scimar.03538. $02 \mathrm{E}$

Baldwin CC, Tornabene L, Robertson DR (2018) Below the mesophotic. Sci Rep 8:4290. https://doi.org/10.1038/s41598-018-23067-1

Benzoni F, Arrigoni R, Stefani F, Reijnen BT, Montano S, Hoeksema BW (2012) Phylogenetic position and taxonomy of Cycloseris explanulata and C. wellsi (Scleractinia: Fungiidae): lost mushroom corals find their way home. Contrib Zool 81:125-146. https://doi. org/10.1163/18759866-08103001

Bongaerts P, Frade PR, Ogier JJ, Hay KB, van Bleijswijk J, Englebert N, Vermeij MJA, Bak RPM, Visser PM, Hoegh-Guldberg O (2013) Sharing the slope: depth partitioning of agariciid corals and associated Symbiodinium across shallow and mesophotic habitats (2-60 m) on a Caribbean reef. BMC Evol Biol 13:205. https://doi.org/10. 1186/1471-2148-13-205

Bongaerts P, Frade PR, Hay KB, Englebert N, Latijnhouwers KRW, Bak RPM, Vermeij MJA, Hoegh-Guldberg O (2015) Deep down on a Caribbean reef: lower mesophotic depths harbor a specialized coralendosymbiont community. Sci Rep 5:7702. https://doi.org/10.1038/ srep07702 
Canário R, Badaró MFS, Johnsson R, Neves EG (2015) A new species of Troglocarcinus (Decapoda: Brachyura: Cryptochiridae) symbiotic with the Brazilian endemic coral Mussismilia (Anthozoa: Scleractinia: Mussidae). Mar Biol Res 11:76-85. https://doi.org/ 10.1080/17451000.2014.894243

Castro P (1976) Brachyuran crabs symbiotic with scleractinian corals: a review of their biology. Micronesica 12:99-110

Castro P (2015) Symbiotic Brachyura. In: Castro P, Davie P, Guinot D, Schram FR, von Vaupel Klein JC (eds.) chapter 71-10. Decapoda: Brachyura, treatise on zoology - anatomy, taxonomy, biology, vol. 9C-I. brill, Leiden and Boston, pp 543-581

Chan BKK, Wong KJH, Cheng YR (2020) Biogeography and host usage of coral-associated crustaceans: barnacles, copepods, and gall crabs as model organisms. In: Thiel M, Poore GC (eds) The natural history of the Crustacea: evolution and biogeography of the Crustacea, vol 8. Oxford University Press, Oxford, pp 183-215

Dinesen Z (1980) A revision of the coral genus Leptoseris (Scleractinia: Fungiina: Agariciidae). Mem Qld Mus 20:181-235

Fenner D (1999) New observations on the stony coral (Scleractinia, Milleporidae, and Stylasteridae) species of Belize (Central America) and Cozumel (Mexico). Bull Mar Sci 64:143-154

Fenner D (2001) Biogeography of three Caribbean corals (Scleractinia) and a rapid range expansion of Tubastraea coccinea into the Gulf of Mexico. Bull Mar Sci 69:1175-1189

Fize A, Serène R (1956) Note préliminaire Sur huit espèces nouvelles, dont Une d'un genre nouveau, d'Hapalocarcinidae. Bull Soc Zool France 80:375-378

Folmer O, Black M, Hoeh W, Lutz R, Vrijenhoek R (1994) DNA primers for amplification of mitochondrial cytochrome c oxidase subunit I from diverse metazoan invertebrates. Mol Mar Biol Biotechnol 3: 294-299

Garcia-Sais JR, Castro R, Sabater-Clavell J, Carlo M, Esteves R (2007) Characterization of benthic habitats and associated reef communities at Bajo de Sico seamount, Mona passage, Puerto Rico. Final report submitted to Caribbean fishery management council (CFMC/NOAA), $91 \mathrm{pp}$

Garcia-Sais JR, Sabater-Clavell J, Esteves R, Capella J, Carlo M (2011) Characterization of benthic habitats and associated mesophotic coral reef communities at El Seco, Southeast Vieques, Puerto Rico. Final report submitted to Caribbean fishery management council (CFMC/NOAA), $102 \mathrm{pp}$

Gittenberger A, Reijnen BT, Hoeksema BW (2011) A molecularly based phylogeny reconstruction of mushroom corals (Scleractinia: Fungiidae) with taxonomic consequences and evolutionary implications for life history traits. Contrib Zool 80:107-132. https://doi.org/ 10.1163/18759866-08002002

Glynn PW, Alvarado JJ, Banks S, Cortés J, Feingold JS, Jiménez C, Maragos JE, Martínez P, Maté JL, Moanga DA, Navarrete S, Reyes-Bonilla H, Riegl B, Rivera F, Vargas-Ángel B, Wieters EA, Zapata FA (2017) Eastern Pacific coral reef provinces, coral community structure and composition: an overview. In: Glynn PW, Manzello DP, Enochs IC (eds) Coral reefs of the eastern tropical Pacific: persistence and loss in a dynamic environment. Springer, Dordrecht, pp 107-176

Gonzalez-Zapata FL, Bongaerts P, Ramírez-Portilla C, Adu-Oppong B, Walljasper G, Reyes A, Sanchez JA (2018) Holobiont diversity in a reef-building coral over its entire depth range in the mesophotic zone. Front Mar Sci 5:29. https://doi.org/10.3389/fmars.2018.00029

Herbert PDN, Penton EH, Burns JM, Hallwachs W (2004) Ten species in one: DNA barcoding reveals cryptic species in the neotropical skipper butterfly Astraptes fulgerator. Proc Natl Acad Sci U S A 101: 14812-14817. https://doi.org/10.1073/pnas.0406166101

Hoeksema BW (2012) Evolutionary trends in onshore-offshore distribution patterns of mushroom coral species (Scleractinia: Fungiidae). Contrib Zool 81:199-221. https://doi.org/10.1163/1875986608104002
Hoeksema BW (2014) The "Fungia patella group" (Scleractinia, Fungiidae) revisited with a description of the mini mushroom coral Cycloseris boschmai sp. n. ZooKeys 371:57-84. https://doi.org/10. 3897/zookeys.371.6677

Hoeksema BW, Cairns S (2020a) World list of Scleractinia. Accessed at $\mathrm{http}: / /$ www.marinespecies.org/scleractinia on 2020-03-22

Hoeksema BW, Cairns S (2020b) World list of Scleractinia. Agaricia Lamarck, 1801. Accessed through: world register of marine species at: http://www.marinespecies.org/aphia.php?p=taxdetails\&id= 204464 on 2020-03-22

Hoeksema BW, García-Hernández JE (2020) Host-related morphological variation of dwellings inhabited by the crab Domecia acanthophora in the corals Acropora palmata and Millepora complanata (southern Caribbean). Diversity 12:143. https://doi.org/10.3390/d12040143

Hoeksema BW, Koh EGL (2009) Depauperation of the mushroom coral fauna (Fungiidae) of Singapore (1860s-2006) in changing reef conditions. Raffles Bull Zool Suppl 22:91-101

Hoeksema BW, ten Hove HA (2017) The invasive sun coral Tubastraea coccinea hosting a native Christmas tree worm at Curaçao, Dutch Caribbean. Mar Biodivers 47:59-65. https://doi.org/10.1007/ s12526-016-0472-7

Hoeksema BW, van der Meij SET (2013) Gall crab city: an aggregation of endosymbiotic crabs inhabiting a colossal colony of Pavona clavus. Coral Reefs 32:59. https://doi.org/10.1007/s00338-0120954-4

Hoeksema BW, Reimer JD, Vonk R (2017a) Editorial: biodiversity of Caribbean coral reefs (with a focus on the Dutch Caribbean). Mar Biodivers 47:1-10. https://doi.org/10.1007/s12526-017-0641-3

Hoeksema BW, Bongaerts P, Baldwin CC (2017b) High coral cover at lower mesophotic depths: a dense Agaricia community at the leeward side of Curaçao, Dutch Caribbean. Mar Biodivers 47:67-70. https://doi.org/10.1007/s12526-015-0431-8

Hoeksema BW, van Beusekom M, ten Hove HA, Ivanenko VN, van der Meij SET, van Moorsel GWNM (2017c) Helioseris cucullata as a host coral at St. Eustatius, Dutch Caribbean. Mar Biodivers 47:7178. https://doi.org/10.1007/s12526-016-0599-6

Hoeksema BW, Butôt R, García-Hernández JE (2018) A new host and range record for the gall crab Fungicola fagei as symbiont of the mushroom coral Lobactis scutaria at Hawai'i. Pac Sci 72:251-261. https://doi.org/10.2984/72.2.7

Hoeksema BW, García-Hernández JE, van Moorsel GWNM, Olthof G, ten Hove HA (2020) Extension of the recorded host range of Caribbean Christmas tree worms (Spirobranchus spp.) with two scleractinians, a zoantharian, and an ascidian. Diversity 12:115. https://doi.org/10.3390/d12030115

Huang D (2012) Threatened reef corals of the world. PLoS One 7: e34459. https://doi.org/10.1371/journal.pone.0034459

Johnsson R, Neves E, Franco GMO, da Silveira FL (2006) The association of two gall crabs (Brachyura: Cryptochiridae) with the reefbuilding coral Siderastrea stellata Verrill, 1868. Hydrobiologia 559:379-384. https://doi.org/10.1007/s10750-005-9307-4

Kitahara MV, Stolarski J, Cairns SD, Benzoni F, Stake JL, Miller DJ (2012) The first modern solitary Agariciidae (Anthozoa, Scleractinia) revealed by molecular and microstructural analysis. Invertebr Syst 26:303-315. https://doi.org/10.1071/IS11053

Klompmaker AA, Boxshall GA (2015) Fossil crustaceans as parasites and hostes. Adv Parasitol 90:233-289. https://doi.org/10.1016/bs. apar.2015.06.001

Klompmaker AA, Portell RW, van der Meij SET (2016) Trace fossil evidence of coral-inhabiting crabs (Cryptochiridae) and its implications for growth and paleobiogeography. Sci Rep 6:23443. https:// doi.org/10.1038/srep23443

Komatsu H, Takeda M (2013) Second record of Luciades agana Kropp and Manning, 1996 (Crustacea, Decapoda, Cryptochiridae) from Tonga, South Pacific. Bull Natl Mus Nat Sci Ser A 39:11-14 
Korzhavina OA, Hoeksema BW, Ivanenko VN (2019) A review of Caribbean Copepoda associated with reef-dwelling cnidarians, echinoderms and sponges. Contrib Zool 88:297-349. https://doi.org/10. 1163/18759866-20191411

Kropp RK (1989) A revision of the Pacific species of gall crabs, genus Opecarcinus (Crustacea: Cryptochiridae). Bull Mar Sci 45:98-129

Kropp RK, Manning RB (1987) The Atlantic gall crabs, family Cryptochiridae (Crustacea: Decapoda: Brachyura). Smithson Contrib Zool 462:1-21

Kropp RK, Manning RB (1996) Crustacea Decapoda: two new genera and species of deep water gall crabs from the indo-West Pacific (Cryptochiridae). Mém Mus Natn Hist Nat Paris Sér A Zool 68: 531-539

Kumar S, Stecher G, Li M, Knyaz C, Tamura K (2018) MEGA X: molecular evolutionary genetics analysis across computing platforms. Mol Biol Evol 35:1547-1759. https://doi.org/10.1093/ molbev/msy096

Manning RB (1991) Crustacea Decapoda: Cecidocarcinus zibrowii, a new deep-water gall crab (Cryptochiridae) from New Caledonia. Mém Mus Natn Hist Nat Paris Sér A Zool 152:515-520

Muir PR, Pichon M (2019) Biodiversity of reef-building, scleractinian corals. In: Loya Y, Puglise KA, Bridge TCL (eds) Mesophotic coral ecosystems. Springer, New York, pp 589-620. https://doi.org/10. 1007/978-3-319-92735-0_33

Muir P, Wallace C, Bridge TCL, Bongaerts P (2015) Diverse staghorn coral fauna on the mesophotic reefs of north-East Australia. PLoS One 10:e0117933. https://doi.org/10.1371/journal.pone.0117933

Muir PR, Wallace CC, Pichon M, Bongaerts P (2018) High species richness and lineage diversity of reef corals in the mesophotic zone. Proc R Soc B 285:20181987. https://doi.org/10.1098/rspb.2018.1987

Nogueira JMM (2003) Fauna living in colonies of Mussismilia hispida (Verrill) (Cnidaria: Scleractinia) in four South-Eastern Brazil Islands. Braz Arch Biol Technol 46:421-432

Nogueira MM, Menezes NM, Johnsson R, Neves E (2014) The adverse effects of cryptochirid crabs (Decapoda: Brachyura) on Siderastrea stellata Verril, 1868 (Anthozoa: Scleractinia): causes and consequences of cavity establishment. Cah Biol Mar 55:155-162

Reyes J, Santodomingo N, Flórez P (2010) Corales Escleractinios de Colombia. In: Instituto de Investigaciones marinas y Costeras (INVEMAR). Colombia, Santa Marta, $246 \mathrm{pp}$

Roberts TE, Bridge TCL, Caley MJ, Madin JS, Baird AH (2019) Resolving the depth zonation paradox in reef corals. Ecology 100: e02761. https://doi.org/10.1002/ecy.2761

Rooney JJ, Donham E, Montgomery A, Spalding HL, Parrish FA, Boland R, Fenner D, Grove J, Vetter O (2010) Mesophotic coral ecosystems in the Hawaiian archipelago. Coral Reefs 29:361-367. https://doi. org/10.1007/s00338-010-0596-3

Sánchez JA, González-Zapata FL, Dueñas LF, Andrade J, Pico-Vargas AL, Vergara DC, Sarmiento A, Bolaños N (2019) Corals in the mesophotic zone $(40-115 \mathrm{~m})$ at the barrier reef complex from San Andrés Island (southwestern Caribbean). Front Mar Sci 6:536. https://doi.org/10.3389/fmars.2019.00536

Santana W, Almeida AO, Lianos L, Mollemberg M (2016) Avaliação dos Caranguejos Criptoquirídeos (Decapoda: Chryptochiridae). Cap 10. In: Pinheiro M, Boos H (Eds). Livro Vermelho dos Crustáceos do Brasil: Avaliação 2010-2014: 143-151. Sociedade Brasileira de Carcinologia, Porto Alegre

Scott PJB (1985) Aspects of living coral associates in Jamaica. Proc $5^{\text {th }}$ Int coral reef Conf 5:345-350

Scott PJB (1987) Associations between corals and macro-infaunal invertebrates in Jamaica, with a list of Caribbean and Atlantic coral associates. Bull Mar Sci 40:271-286

Semmler RF, Hoot WC, Reaka ML (2017) Are mesophotic coral ecosystems distinct communities and can they serve as refugia for shallow reefs? Coral Reefs 36:433-444. https://doi.org/10.1007/s00338016-1530-0
Shaw JK, Hopkins TS (1977) The distribution of the family Hapalocarcinidae (Decapoda, Brachyura) on the Florida middle ground with a description of Pseudocryptochirus hypostegus new species. Proc $3^{\text {rd }}$ Int coral reef Symp 1:177-183

Sherman C, Nemeth RH, Bejarano I, Appeldoorn R, Pagan F, Schärer M, Weil E (2010) Geomorphology and benthic cover of mesophotic coral ecosystems of the upper insular slope of Southwest Puerto Rico. Coral Reefs 29:347-360. https://doi.org/10.1007/s00338010-0607-4

Simon-Blecher N, Achituv Y (1997) Relationship between the coral pit crab Cryptochirus coralliodytes Heller and its host coral. J Exp Mar Biol Ecol 215:93-102. https://doi.org/10.1016/S0022-0981(97) 00002-6

Simon-Blecher N, Chemedanov A, Eden N, Achituv Y (1999) Pit structure and trophic relationship of the coral pit crab Cryptochirus coralliodytes. Mar Biol 134:711-717. https://doi.org/10.1007/ s002270050587

Slattery M, Lesser MP, Brazeau D, Stokes MD, Leichter JJ (2011) Connectivity and stability of mesophotic coral reefs. J Exp Mar Biol Ecol 408:32-41. https://doi.org/10.1016/j.jembe.2011.07.024

Takeda M, Tamura Y (1980) Coral-inhabiting crabs of the family Hapalocarcinidae from Japan. II. Genus Pseudohapalocarcinus. Proc Jap Soc Syst Zool 18:54-58

van der Meij SET (2014a) A new species of Opecarcinus Kropp \& Manning, 1987 (Crustacea: Brachyura: Cryptochiridae) associated with the stony corals Pavona clavus (Dana, 1846) and P. bipartita Nemenzo, 1980 (Scleractinia: Agariciidae). Zootaxa 3869:44-52. https://doi.org/10.11646/zootaxa.3869.1.4

van der Meij SET (2014b) Host species, range extensions, and an observation of the mating system of Atlantic shallow-water gall crabs (Decapoda: Cryptochiridae). Bull Mar Sci 90:1001-1010. https:// doi.org/10.5343/bms.2014.1017

van der Meij SET (2015) Host relations and DNA reveal a cryptic gall crab species (Crustacea: Decapoda: Cryptochiridae) associated with mushroom corals (Scleractinia: Fungiidae). Contrib Zool 84:39-57. https://doi.org/10.1163/18759866-08401004

van der Meij SET (2017) The coral genus Caulastraea Dana, 1846 (Scleractinia, Merulinidae) as a new host for gall crabs (Decapoda, Cryptochiridae), with the description of Lithoscaptus tuerkayi sp. nov. Crustaceana 90:1027-1038. https://doi.org/10.1163/ 9789004366435019

van der Meij SET, Nieman AM (2016) Old and new DNA unweave the phylogenetic position of the eastern Atlantic gall crab Detocarcinus balssi (Monod, 1956) (Decapoda: Cryptochiridae). J Zool Syst Evol Res 54:189-196. https://doi.org/10.1111/jzs.12130

van der Meij SET, Reijnen BT (2014) The curious case of Neotroglocarcinus dawydoffi (Decapoda, Cryptochiridae): unforeseen biogeographic patterns resulting from isolation. Syst Biodivers 12:503-512. https://doi.org/10.1080/14772000.2014.946979

van der Meij SET, van Tienderen KM, Hoeksema BW (2015a) A mesophotic record of the gall crab Opecarcinus hypostegus from a Curaçaoan reef. Bull Mar Sci 91:205-206. https://doi.org/10.5343/ bms.2014.1072

van der Meij SET, Fransen CHJM, Pasman LR, Hoeksema BW (2015b) Phylogenetic ecology of gall crabs (Cryptochiridae) as associates of mushroom corals (Fungiidae). Ecol Evol 5:5770-5780. https://doi. org/10.1002/ece3.1808

van der Meij SET, Benzoni F, Berumen ML, Naruse T (2018) New distribution records of the gall crab Opecarcinus cathyae van der Meij, 2014 (Decapoda: Brachyura: Cryptochiridae) from the Red Sea, Maldives and Japan. Mar Biodivers 48:1611-1613. https:// doi.org/10.1007/s12526-016-0598-7

van Moorsel GWNM, van der Meij SET (2018) The stony coral Agaricia tenuifolia Dana, 1848 as a new gall crab host (Decapoda: Cryptochiridae). Nauplius 26:e2018002. https://doi.org/10.1590/ 2358-2936e2018002 
van Tienderen KM, van der Meij SET (2016) Occurrence patterns of coral-dwelling gall crabs (Cryptochiridae) over depth intervals in the Caribbean. PeerJ 4:e1794. https://doi.org/10.7717/peerj.1794

van Tienderen KM, van der Meij SET (2017) Extreme mitochondrial variation in the Atlantic gall crab Opecarcinus hypostegus (Decapoda: Cryptochiridae) reveals adaptive genetic divergence over Agaricia coral hosts. Sci Rep 7:39461. https://doi.org/10. 1038/srep39461

Veglia AJ, Hammerman NH, Rivera Rosaly CR, Lucas MQ, Galindo A, Estronza Corgosinho PH, Schizas NV (2018) Characterizing population structure of coral-associated fauna from mesophotic and shallow habitats in the Caribbean. J Mar Biol Assoc UK 99:619-629. https://doi.org/10.1017/S0025315418000413

Waheed Z, Benzoni F, van der Meij SET, Terraneo TI, Hoeksema BW (2015) Scleractinian corals (Fungiidae, Agariciidae and Euphylliidae) of Pulau Layang-Layang, Spratly Islands, with a note on Pavona maldivensis (Gardiner, 1905). ZooKeys 517:1-37. https://doi.org/10.3897/zookeys.517.9308
Wei TP, Hwang JS, Tsai ML, Fang LS (2005) New records of gall crabs (Decapoda, Cryptochiridae) from Orchid Island, Taiwan, northwestern Pacific. Crustaceana 78:1063-1077. https://doi.org/10.1163/ 156854005775361025

Wells JW (1973) New and old scleractinian corals from Jamaica. Bull Mar Sci 23:16-58

Wetzer R, Martin JW, Boyce SL (2009) Evolutionary origin of the gall crabs (family Cryptochiridae) based on $47516 \mathrm{~S}$ rDNA sequence data. In: Martin JW, Crandall KA, Felder DL (eds) Decapod crustacean Phylogenetics. CRC Press, Boca Raton, pp 475-490

Zibrowius H, Gili J-M (1990) Deep-water Scleractinia (Cnidaria: Antbozoa) from Namibia, South Africa, and Walvis Ridge, southeastern Atlantic. Sci Mar 54:19-46

Publisher's note Springer Nature remains neutral with regard to jurisdictional claims in published maps and institutional affiliations. 